\title{
Peran Bantuan Ahli Ilmu Kedokteran Forensik dalam Pembuktian Perkara Tindak Pidana Pembunuhan pada Tahap Penyidikan
}

\author{
Luthfi Arya Ravi Pambudi ${ }^{1}$, Heri Purwanto ${ }^{2}$ \\ ${ }^{1,2}$ Program Studi Hukum, Fakultas Hukum, Universitas Muhammadiyah Yogyakarta, Indonesia \\ Jl. Brawijaya, Tamantiro, Kasihan, Bantul, Yogyakarta \\ E-mail: ${ }^{1}$ luthfi.arya.2015@law.umy.ac.id; ${ }^{2}$ mheripurwanto@umy.ac.id
}

\section{Info Artikel}

Diajukan: 22-02-2020

Direview: 21-03-2020

Direvisi: 26-03-2020

Diterima: 01-04-2020

DOI: $10.18196 / \mathrm{mls} . v 1 i 2.8345$

\begin{abstract}
Abstrak
Dalam suatu pembuktian perkara pidana yang berkaitan dengan tubuh dan atau jiwa manusia Ilmu kedokteran forensik mempunyai peranan yang sangat penting. Penelitian ini adalah penelitian hukum normatif penelitian ini untuk mempelajari bagaimana proses penegakan hukum yang dilakukan oleh aparat penegak hukum yaitu Kepolisian sebagai penyidik, bidang hukum dan bidang kedokteran sangat berkaitan dalam rangkaian pembuktian perkara tindak pidana pembunuhan
\end{abstract} dikarenakan tidak kemampuan ilmu yang dimiliki dari penyidik maupun hakim dalam menangani perkara tindak pidana pembunuhan yang berkaitan dengan tubuh dan jiwa manusia, dalam penelitian ini mencari bagaimana peran ilmu kedokteran forensik dalam membantu penyidik untuk menemukan kebenaran materiil pada perkara tindak pidana pembunuhan, berdasarkan hasil penelitian dilapangan, peran bantuan ilmu kedokteran forensik sangat diperlukan untuk menemukan kebenaran materiil pada perkara tindak pidana pembunuhan agar dapat membuat terang perkara pidana tersebut dan memperoleh alat bukti yang sah, tetapi tidak selamanya peran ilmu kedokteran forensik berhasil, terdapat juga hambatan-hambatan yang terjadi. Kesimpulan yang diambil dari penelitian ini untuk aparat penegak hukum perlu adanya koordinasi dengan dokter forensik dan harus mengedepankan keadilan sebagai dasar melakukan penyidikan.

Kata kunci: ahli, alat bukti, hukum acara pidana, kedokteran forensik, penyidikan.

\section{Pendahuluan.}

Hukum acara pidana yang berlaku di Indonesia saat ini adalah Undang-Undang Nomor 8 Tahun 1981 tentang Hukum Acara Pidana, yang disebut dengan KUHAP (Kitab Undang-undang Hukum Acara Pidana) yang dimana sudah diundangkan pada tanggal 31 Desember 1981. Hukum pidana merupakan hukum materiil dan hukum acara pidana merupakan hukum formil yaitu kumpulan peraturan-peraturan yang dimana mengatur tata cara atau prosedur penegakan hukum pidana materiil menggunakan alatalat Negara di muka pengadilan pidana. ${ }^{1}$

Tujuan dari Ilmu kedokteran forensik untuk membantu menentukan suatu tindak pidana yang menyebabkan hilangnya nyawa manusia atau cacatnya manusia akibat dari

\footnotetext{
${ }^{1}$ Bambang Poernomo, 1982, Seri Hukum Acara Pidana Pandangan Terhadap Asas-asas Umum Hukum Acara Pidana, Yogyakarta, Liberty, hlm.2
} 
tindak pidana yang dilakukan oleh seseorang, bantuan dari ilmu kedokteran forensik nantinya akan tertuang pada alat bukti Visum et Repertum, alat bukti Visum et Repertum akan berfungsi sebagai pengganti corpus delicti (barang hasil kejahatan) yang nyatanyata tidak bisa atau tidak mungkin dihadirkan dalam sidang contohnya seperti luka pada tubuh manusia atau korban yang sudah meninggal. Oleh sebab itu, pembuatan Visum et Repertum harus dilakukan secara teliti, cermat dan lengkap berdasarkan apa yang dilihat dan diketemukan oleh dokter yang memeriksa mayat tersebut. Mengingat sedemikian penting peran Visum et Repertum ini dalam pembuktian maka adanya sedikit saja kelalaian akan menimbulan kesalahan dalam proses pidananya termasuk penjatuhan hukuman oleh hakim tujuan ilmu kedokteran forensik adalah menentukan hubungan yang menyebabkan sesuatu kejadian tindak pidana yang menyebabkan kecederaan atau gangguan kesehatan dan sama sekali tidak bertujuan untuk menyembuhkan. ${ }^{2}$

Salah satu fokus utama dari pembahasan diatas yaitu untuk memperoleh alat bukti dalam tindak pidana pembunuhan adalah barang bukti mikro (micro evidence) yaitu bagaimana barang bukti didapatkan (proses olah TKP, proses penindakan), dimana barang bukti tersebut diawetkan agar tidak rusak dan dapat diperiksa atau identifikasi (proses pemeriksaan laboratorium) dan adanya pemanfaatan hasil pemeriksaan laboratorium kriminalistik, barang bukti dan teknis kriminalistik, Tempat Kejadian Perkara dalam proses pemeriksaan saksi-saksi atau tersangka oleh penyidik. Seperti yang diketahui bahwa dalam barang bukti terdapat unsur mikro dan unsur makro. Unsur mikro apabila dilakukan pemeriksaan di laboratorium atau oleh ahlinya akan menjadi alat bukti keterangan saksi dan atau surat (Berita Acara/BA) dan atau bukti petunjuk, sedangkan unsur makro apabila dipergunakan dalam pemeriksaan saksi atau tersangka oleh penyidik dan dibuatkan berita acara (BA) akan menjadi alat bukti, keterangan saksi dan atau keterangan tersangka. ${ }^{3}$

Usaha-usaha yang dilakukan oleh para penegak hukum untuk mencari kebenaran materiil suatu perkara pidana dimaksudkan untuk menghindari adanya kekeliruan dalam penjatuhan pidana terhadap diri seseorang, hal ini sebagimana ditentukan dalam Undang-Undang No.4 Tahun 2004 tentang Ketentuan Pokok Kekuasaan Kehakiman Pasal 6 ayat (2) yang menyatakan: "Tiada seorangpun dapat dijatuhi pidana, kecuali apabila pengadilan karena alat pembuktian yang sah menurut Undang - undang mendapat keyakinan bahwa seseorang yang diangggap dapat bertanggung jawab, telah bersalah atas perbuatan yang dituduhkan atas dirinya".

Berdasarkan uraian diatas, penulis tertarik untuk mengkaji lebih lanjut pada Peran ilmu kedokteran forensik dalam membantu penyidik untuk menemukan kebenaran materiil pada perkara tindak pidana pembunuhan.

\footnotetext{
${ }^{2}$ Herkutanto, 2006, Visum et Repertum dan Pelaksanaanya, Jakarta, Ghalia, hlm. 166.

${ }^{3}$ ASIS, R. A. "Peranan Unit Identifikasi Dalam Proses Penyidikan Untuk Mengungkap Tindak Pidana". Dikutip pada 23 Oktober 2018, pada pukul 19.00
} 


\section{Metode Penelitian.}

\subsection{Jenis Penelitian}

Penelitian ini adalah penelitian hukum normatif, yaitu penelititan hukum yang meletakkan hukum sebagai sebuah bangunan sistem norma. Sistem norma yang dimaksud adalah mengenai asas - asas, norma, kaidah dari peraturan perundangundangan, putusan pengadillan, perjanjian serta doktrin (ajaran). ${ }^{4}$

\subsection{Sumber Data}

Penelitian ini menggunakan data sekunder sebagai sumber data, untuk mendapatkan sumber data tersebut peneliti menggunakan studi kepustakaan yang mengkaji bahan hukum. Bahan hukum tersebut terdiri dari bahan primer, bahan hukum sekunder dan bahan hukum non-hukum. Pada penelitian ini terdapat 3 (tiga) bahan hukum yakni bahan hukum primer, bahan hukum sekunder, dan badan hukum tersier.

a. Bahan Hukum Primer

Bahan hukum primer adalah bahan hukum yang diperoleh dan secara langsung digunakan dalam penelitian. Bahan hukum primer yang digunakan dalam penelitian ini seperti Peraturan Perundang-Undangan yang berelevan.

b. Bahan Hukum Sekunder

Bahan hukum sekunder adalah bahan-bahan yang erat kaitannya dengan bahan hukum primer dan dapat membantu menganalisis mampu memahami bahan hukum primer, meliputi dokumen-dokumen dan literatur-literatur yang ada hubungannya dengan masalah hukum pidana dan hukum acara pidana khususnya berkaitan dengan ilmu kedokteran forensik dan penyidikan berbasis ilmiah menggunakan ilmu kedokteran forensik Berikut bahan hukum sekunder yang digunakan dalam penelitian ini, antara lain:

1. Buku- buku yang terkait dalam penulisan skripsi.

2. Bahan-bahan acuan yang relevan dengan rumusan masalah, baik dalam bentuk mekanik (hard file) maupun elektronik (soft file).

3. Berita internet.

4. Surat kabar.

\section{c. Bahan Hukum Non-Hukum}

Yaitu bahan-bahan hukum yang memberikan petunjuk maupun penjelasan terhadap bahan hukum primer dan bahan hukum sekunder, yaitu kamus hukum. penelitian ini yaitu:

1. Kamus Besar Bahasa Indonesia;

2. Kamus Hukum;

3. Kamus Besar Bahasa Inggris-Indonesia

Untuk melengkapi data dari bahan-bahan hukum primer dan sekunder, maupun non-hukum penulis menambahkan data dengan cara wawancara terstruktur dengan

\footnotetext{
${ }^{4}$ Mukti Fajar, 2010, Dualisme Penelitian Hukum Normatif \&Empiris, Yogyakarta, Pustaka Pelajar, Hlm 34.
} 
narasumber secara langsung yang dimana lokasi yang dipilih untuk penelitian ini yaitu Kantor Kepolisian Indonesia Resort Kabupaten Purworejo.

Dalam penelitian ini yang bertindak sebagai narasumber adalah:

1. Penyidik Kantor Kepolisian Indonesia Resort Kabupaten Purworejo AKP R.Harya Seto, S.H., M.Krim.

2. Dokter Forensik, dr. Dirwan Suryo Sularto, Sp.F., M.Sc.

\section{Hasil dan Pembahasan}

\subsection{Peran ilmu kedokteran forensik dalam membantu penyidik untuk menemukan kebenaran materiil pada perkara tindak pidana pembunuhan}

Bantuan dari seorang ahli diperlukan dalam suatu proses penyidikan perkara pidana baik dalam tahap pemeriksaaan pendahuluan dan pada tahap pemeriksaan lanjutan disidang pengadilan, ahli mempunyai peran penting dalam membantu aparat yang berwenang dalam menangani kasus perkara pidana tersebut, bantuan dari ahli berguna untuk membantu membuat terang suatu perkara pidana, dan dapat membantu mengungkap siapa pelaku tindak pidana. Ahli kedokteran forensik dalam persidangan dapat membantu Hakim proses pembuktian di peradilan sehingga dengan tambahan keterangan ahli kedokteran forensik Hakim dapat menjatuhkan putusan dengan tepat terhadap perkara yang diperiksanya.

Peran bantuan dari ahli ilmu kedokteran forensik dilakukan untuk pembuktian yang digunakan untuk mengajukan alat bukti yang sah kedepan persidangan, guna mendapatkan atau setidak-tidaknya mendekati kebenaran materiil dalam pembuktian harus dilakukan pembuktian secara ilmiah ${ }^{5}$

Berdasarkan pasal 7 ayat 1 sub h KUHAP pada proses penyidikan dalam mengungkap suatu tindak pidana penyidik mempunyai wewenang untuk mendatangkan orang ahli yang diperlukan dalam hubungnnya dengan pemeriksaan perkara, Pada kasus yang ditangani Kepolisian Resort Purworejo tentang pembunuhan yang terjadi diwilayah hukum Polres Purworejo tepatnya di Desa Panggeldlangu, Kecamatan Butuh, Kabupaten Purworejo, yang dilakukan oleh Gunardi 36 tahun kepada korban yang ternyata istri pelaku Siti Sarah Apriyani 32 tahun, dan juga ibu mertuanya Endang Susilowati 50 tahun, dan selain itu pelaku juga melakukan penganiayaan terhadap anak dan ayah mertuanya Muh Wahyono 65 tahun. Berdasarkan keterangan Penyidik AKP R. Harya Seto, S.H., M. Krim. peristiwa ini awalnya diketahui tetangga korban yang mendengar teriakan minta tolong dirumah mertua pelaku. Diketahui pelaku bersama istri dan anaknya juga tinggal dirumah tersebut, pada saat tetangga berdatangan karena mendengar kegaduhan, korban sudah tergeletak dilantai dan kemudian menghubungi polisi, istri pelaku dinyatakan tewas dilokasi kejadian, dan ibu mertuanya meninggal dunia setelah sempat dirawat di rumah sakit, keduanya luka parah akibat senjata tajam. dengan ini yang berkaitan dengan kasus tersebut penyidik dapat melaksanakan ketentuan sebagai berikut:

\footnotetext{
${ }^{5}$ Wawancara dengan Penyidik AKP R. Harya Seto, S.H., M. Krim.
} 
1. Pasal 120 ayat 1 "dalam hal ini penyidik menanggap perlu, ia dapat diminta orang ahli atau orang yang memiliki keahlian khusus"

2. Pada pasal tersebut tidak disebutkan TKP, dikantor atau ditempat lainnya

3. Bantuan yang dapat dimintakan kepada ahli berupa pemeriksaan di TKP atau di Rumah sakit. Pemeriksaaan dilakukan berdasakan pengetahuan yang sebaikbaiknya.

4. Pada kasus terbaru tersebut yang terjadi di wilayah hukum Polres Purworejo Penyidik AKP R.Harya Seto, S.H., M.Krim selaku penyidik meminta bantuan dari Ilmu kedokteran forensik rumah sakit Bhayangkara Semarang, dalam penangan kasus pembunuhan yang terjadi di Purworejo, penyidik meminta dokter forensik untuk melakukan pemeriksaan di tempat kejadian perkara sesuai dengan Hukum Acara Pidana yang berlaku dan sesuai pula dengan Pasal 13 Undang-undang Pokok Kepolisian Tahun 1961 Nomor 13, dan selama pemeriksaan dilakukan dihindari tindakan-tindakan yang dapat merubah, mengganggu atau merusak keadaan tempat kejadian perkara, dalam pemeriksaan tempat kejadian perkara yang merupakan tahap awal dokter forensik mengumpulkan barang bukti yang ada kaitanya dengan manusia, seperti bercak darah yang terdapat pada tempat kejadian perkara, dan mengumpulkan bendabenda yang ada kaitannya dengan kematian korban. Pemeriksaan di TKP disebut dengan Visum et Repertum TKP, manfaat dari pemeriksaan di TKP, yaitu:

a. Menentukan saat kematian,

b. Menentuan pada saat itu sebab akibat dari luka,

c. Mengumpulkan barang bukti yang ada di TKP,

d. Menentukan cara kematian dari korban.

Prosedur pemeriksaan di TKP:

a. Untuk mempersingkat waktu permintaan bantuan dari ahli dapat secara lisan dan atau telepon,

b. Selanjutnya disusul dengan cara tertulis,

c. Dokter dijemput dan diantar kembali oleh penyidik atau petugas Kepolisian,

d. Untuk pemeriksaan tersebut, dokter harus didampingi oleh penyidik dan pangkat dari penyidik serendah-rendahnya Letnan Dua atau Inspektur dua. ${ }^{6}$

Pada saat penyidik menerima bantuan dari ahli dalam penyidikan perkara tindak pidana maka dokter harus mencatat:

a. Tanggal dokter menerima permintaan bantuan dari penyidik,

b. Cara permintaan bantuan dari penyidik,

c. Nama penyidik yang meminta bantuan,

d. Jam saat dokter tiba di TKP,

e. Alamat TKP dan macam tempatnya (contoh: rumah, gedung, sawah, jalan)

\footnotetext{
${ }^{6}$ Wawancara dengan dr. Dirwan Suryo Sularto, Sp. F, M.Sc.
} 
f. Hasil pemeriksaan. ${ }^{7}$

Tindakan yang dilakukan ahli pada TKP yaitu:

a. Dalam pemeriksaan dokter harus berkoordinasi dengan penyidik yang berwenang,

b. Menentukan korban masih dalam keadaan hidup, atau sudah tidak bernyawa,

c. Apabila korban masih hidup diharuskan terlebih dahulu menangani korban,

d. Apabila korban sudah tidak bernyawa maka dapat dibiarkan sesuai dengan adanya,

e. Tidak memindahkan jenasah sebelum seluruh pemeriksaaan di TKP selesai,

f. Area TKP harus diamankan oleh penyidik agar dokter dapat memeriksa,

g. Apabila yang tidak berkepentingan dan berkepentingan dikeluarkan dari TKP agar tidak mengganggu jalannya pemeriksaan oleh dokter di TKP,

h. Pencatatan identitas dari orang tersebut. ${ }^{8}$

Pada proses pemeriksaan mayat korban tindak pidana di TKP, dokter selaku ahli akan memeriksa mayat dan juga kondisi sekitarnya, terdapat beberapa hal yang perlu dicatat dokter yaitu:

a. Lebam mayat,

b. Kuku mayat,

c. Suhu tubuh korban

d. Luka-luka

e. Membuat sketsa dan atau foto,

f. Mencari dan mengumpulkan barang bukti yang ada di TKP,

g. Dokter harus tetap berkoordinasi dengan penyidik,

h. Dokter membantu mencari barang bukti, (contoh: racun, anak peluru, senjata tajam)

i. Segala barang bukti yang ditemukan diserahkan kembali kepada penyidik yang bersangkutan,

j. Dokter juga dapat meminjam barang bukti tersebut demi kepentingan pemeriksaan lebih lanjut,

k. Selesai pemeriksaan, TKP ditutup dengan garis polisi,

1. Korban yang masih hidup atau sudah dalam keadaan tidak bernyawa dibawa ke Rumah Sakit dan dengan disertai permohonan permintaan pemeriksaan Visum et Repertum dari pihak Kepolisian. ${ }^{9}$

Tahap selanjutnya tugas dari kedokteran forensik rumah sakit Bhayangkara Semarang yang diminta untuk mengidentifikasi korban pembunuhan yang dilaksanakan di RSUD Dr. Tjitrowardojo dengan meminjam ruangan untuk melaksanakan identifikasi pada korban pembunuhan, hal tersebut diperbolehkan AKP R.Harya Seto, S.H., M.Krim selaku penyidik dikarenakan alasan keadaan yang tidak memungkinkan untuk

\footnotetext{
${ }^{7}$ Wawancara dengan dr. Dirwan Suryo Sularto, Sp. F, M.Sc.

${ }^{8}$ Wawancara dengan dr. Dirwan Suryo Sularto, Sp. F, M.Sc.

${ }^{9}$ Wawancara dengan dr. Dirwan Suryo Sularto, Sp. F, M.Sc.
} 
melaksanakan identifikasi bedah mayat atau autopsi korban di rumah sakit Bhayangkara Semarang, dalam pemeriksaan bedah mayat atau autopsi, dokter forensik hanya melakukan pemeriksaan luar jenazah. Faktor-faktor yang digunakan Kedokteran Forensik untuk menentukan saat terjadinya kematian adalah:

a. Livor mortis (lebam jenazah)

b. Rigor mortis (kaku jenazah)

c. Body temperature (suhu badan)

d. Degree of decomposition (derajat pembusukan)

e. Insect activity (aktifitas serangga)

f. Scene markers (tanda-tanda yang ditemukan pada sekitar tempat kejadian). ${ }^{10}$

Untuk kepentingan penegakan hukum dan peradilan dapat dilakukan bedah mayat forensik sesuai dengan ketentuan peraturan perundang-undangan, dalam hal ini yang berwenang melakukan pemeriksaan mayat maupun korban luka menurut Pasal 133 KUHAP adalah:

a. Ahli kedokteran kehakiman

b. Dokter/ahli

Sedangkan menurut Pasal 122 ayat 2 Undang-undang Nomor 36 tahun 2009, bedah mayat forensik dilakukan oleh ahli kedokteran forensik, atau oleh dokter lain apabila tidak ada dokter ahli forensik dan perujukan ketempat yang terdapat ahli forensik tidak memungkinakan. ${ }^{11}$

Dalam tahap pemeriksaan terdapat tata cara autopsi, sebelum dilaksanakannya pemeriksaan luar harus dimulai terlebih dahulu dengan mengidentifikasi mayat. Dokter harus tahu dengan pasti bahwa mayat yang akan diperiksa betul-betul mayat yang dimaksudkan dalam surat permintaan Visum et Repertum yang diminta oleh penyidik Kepolisian, hal itu dilaksanakan untuk menghindari penukaran mayat yang mubgkin dapat terjadi apabila mayat yang diperiksa lebih dari satu, dan pada mayat terdapat meterai pada ibu jari kaki atau pada bagian badan mayat. Menurut Pasal 133 ayat 3 KUHAP dijelaskan, dalam hal ini penyidik tidak perlu mengikat sendiri label pada ibu jari kaki mayat, tetapi dapat meminta bantuan kepada petugas bagian kedokteran forensik untuk melakukan itu atas petunjuknya. ${ }^{12}$

Dari hasil wawancara tentang kasus tindak pidana pembunuhan yang terjadi di Purworejo yang dimana penyidik meminta bantuan dari ahli kedokteran forensik dari rumah sakit Bhayangkara Semarang, dengan itu dokter forensik mengeluarkan hasil Visum et Repertum TKP dan Visum et Repertum pemeriksaan luar pada jenazah korban, kemudian digunakan penyidik sebagai alat bukti yang sah secara hukum, dan didalamnya dijelaskan mengenai keadaan terakhir korban misal setelah terjadinya tindak pidana penganiayaan, pemerkosaan, maupun korban yang berakibat dari tindak

\footnotetext{
${ }^{10}$ Anis Nurwidayati, 2009 “Penerapan Entomologi dalam Bidang Kedokteran Forensik”, Jurnal Vektor Penyakit Vol. III, No. 2, hlm 56

${ }^{11}$ M. Soekry Erfan Kusuma, dkk, 2012, "Ilmu Kedokteran Forensik dan Medikolegal, Surabaya, Fakultas Kedokteran Universitas Airlangga, hlm. 204-205

${ }^{12}$ Wawancara dengan dr. Dirwan Suryo Sularto, Sp. F, M.Sc.
} 
pidana tersebut kehilangan nyawanya, hal tersebut dinyatakan oleh dokter setelah memeriksa korban. ${ }^{13}$

Pada kelanjutan kasus setelah dokter forensik mengeluarkan surat Visum et Repertum tersebut, Kapolres Purworejo, AKBP Indra K Mangusong kemudian menjelaskan bahwa dengan hasil Visum et Repertum yang dikeluarkan oleh kedokteran forensik dari rumah sakit Bhayangkara Semarang dijadikan alat bukti dalam perkara tindak pidana pembunuhan sehingga tersangka kasus tindak pidana pembunuhan tersebut dijerat dengan dakwaan primer Pasal 340 KUHP tentang Pembunuhan dengan sengaja subsidair Pasal 338 KUHP tentang pembunuhan, atau Pasal 44 ayat 3 Undangundang Nomor 23 tahun 2004 tentang Penghapusan Kekerasan Dalam Rumah Tangga, dan Pasal 351 KUHP tentang Penganiayaan.

Penulis dalam hal ini juga mencari kasus pembanding,Berdasarkan wawancara kepada dr. Dirwan Suryo Sularto, Sp.F, M.Sc. pernah mengalami kejanggalan pada saat melakukan bedah mayat atau autopsi sebagai contoh pada pelaksaan bedah mayat atau autopsi terduga teroris Siyono, dr. Dirwan Suryo Sularto, Sp.F, M.Sc. tergabung dalam tim doter forensik Muhammadiyah yang diminta Komisi Nasional Hak Asasi Manusia untuk melaksanakan bedah mayat atau autopsi ulang yang dilaksanakan ditempat pemakaman terduga Siyono.

Pada pelaksanaan bedah mayat atau autopsi tersebut terdapat beberapa kejanggalan terhadap kondisi jenazah Siyono yaitu terdapat patah tulang iga bagian kiri dan ada lima ke bagian dalam, luka parah sebelah kanan ada satu keluar, tulang dada Siyono dalam kondisi patah dan mengarah kejantung, terdapat juga luka lebam pada tengkorak kepala Siyono, dengan hasil pemeriksaan tersebut Siyono yang diduga meninggal karena kecelakaan berdasarkan tanggapan Polri dikarenakan Siyono diduga menyerang anggota Densus 88 sehingga perkelahian yang menyebabkan Siyono meninggal. Akan tetapi pendapat dari dr. Dirwan Suryo Sularto, Sp.F, M.Sc. selaku tim dokter forensik Muhammadiyah menjelaskan bahwa diduga Siyono mengalami penyiksaan sehingga meninggal pada saat penyelidikan.

Pada kasus tindak pidana pembunuhan penyidikan berbasis ilmiah yang dilakukan Ilmu Kedokteran Forensik dalam proses untuk memperoleh alat bukti dalam kasus tindak pidana sangat diperlukan untuk membantu penyidik mengungkap sebuah kasus yang berkaitan dengan tubuh dan jiwa manusia, tetapi pada penelitian ini ditemukan bahwa ada hasil forensik yang tidak sesuai dengan kenyataan yang dibuat oleh ahli kedokteran forensik Polri sesuai dengan keterangan dari dr. Dirwan Suryo Sularto, Sp.F, M.Sc., maka kedepannya penyidik harus mengedepankan keadilan sebagai dasar dalam melakukan penyidikan sehingga perlindungan terhadap Hak Asasi Manusia mengenai hak-hak tersangka dan juga hak-hak dari korban harus diperhatikan dengan baik.

Peran bantuan ahli ilmu kedokteran forensik dalam pembuktian perkara tindak pidana pembunuhan yang dilakukan pada tahap penyidikan juga terdapat faktor

\footnotetext{
${ }^{13}$ Wawancara dengan dr. Dirwan Suryo Sularto, Sp. F, M.Sc.
} 
penghambat dalam bantuan ilmu kedokteran forensik dalam pembuktian perkara tindak pidana pembunuhan. Merujuk kepada pasal 184 KUHAP yang dimana sudah dijelaskan diatas, bahwa keterangan ahli dapat dijadikan sebagai sebuah alat bukti yang sah, dan tambahan lainnya ada di dalam pasal 1 angka 28 KUHAP menyatakan bahwa, keterangan ahli adalah keterangan yang diberikan oleh seorang yang memiliki keahlian khusus tentang hal yang diperlukan untuk membuat terang suatu perkara pidana guna kepentingan pemeriksaan yang sedang dilaksanakan

Keterangan seorang ahli sebagai alat bukti yang sah dan sesuai dengan Pasal 1 angka 28 KUHAP adalah "keterangan yang diberikan oleh seseorang yang diperlukan untuk membuat terang suatu perkara pidana guna kepentingan pemeriksaan" juga Yahya Harahap berpendapat keterangan ahli sebagai salah satu alat bukti yang sah dimata hukum Indonesia dan merupakan salah satu kemajuan dari hukum acara pidana di negara Indonesia. Yahya Harahap menuliskan analisa dari seorang ahli merupakan alat bukti yang penting dalam pemeriksaan perkara tindak pidana yang dilakukan oleh seseorang. ${ }^{14}$

Pada kasus yang diteliti penulis tentang tindak pidana pembunuhan yang terjadi diwilayah hukum Polres Purworejo, dari hasil penelitian yang dilakukan dapat disimpulkan bahwa peran dari kedokteran forensik digunakan oleh penyidik untuk mengungkap tindak pidana.

Pada pembahasan tentang forensik terdapat hambatan atau kendala dalam prakterknya yaitu sebagai berikut:

a. Kurangnya ahli dokter forensik, Pada saat ini akibat sedikitnya jumlah dokter forensik sedangkan kasus tindak pidana yang cukup banyak diwilayah Jawa Tengah dan Daerah Istimewa Yogyakarta membuat penanganan awal yang membutuhkan pemeriksaan luar ditangani oleh dokter umum terlebih dahulu, prinsip dokter umum dalam prioritas utamanya yaitu mengobati dan menyelamatkan nyawa korban terlebih dahulu, sehingga membuat pengumpulan benda atau barang bukti dan tata cara pemeriksaanya membuat barang bukti yang penting terlewatkan

b. Pembuatan Visum et Repertum yang tidak dilakukan sesegera mungkin, pada prinsip dokter forensik adalah waktu pemeriksaan, semakin cepat dokter forensik dalam memeriksa barang bukti dalam hal ini jenazah ataupun korban hidup, maka akan semakin banyak juga informasi yang dapat didapat dari hasil pemeriksaan tersebut.

c. Pihak keluarga yang mengajukan keberatan, dalam melaksanakan pemeriksaan keluarga korban sering tidak menyetujui pemeriksaan bedah mayat atau autopsi dikarenakan keyakinan agama. ${ }^{15}$

\section{Simpulan}

\subsection{Simpulan}

\footnotetext{
${ }^{14}$ M. Yahya Harahap, 2000, Pembahasan Permasalahan Dan Penerapan KUHAP, Pemeriksaan Sidang Pengadilan, Banding, Kasasi dan Peninjauan Kembali, Jakarta, Sinar Grafika, hlm 276.

${ }^{15}$ Wawancara dengan Penyidik AKP R. Harya Seto, S.H., M. Krim
} 
Berdasarkan pemaparan dari hasil penelitian tentang peran bantuan ahli ilmu kedokteran forensik dalam pembuktian perkara tindak pidana pembunuhan pada tahap penyidikan yaitu pada proses penanganan perkara tindak pidana dalam hal ini berdasarkan hasil penelitian yang dilakukan oleh peneliti mengangkat kasus tindak pidana pembunuhan yang baru saja terjadi diwilayah hukum Polres Purworejo dan sedang dalam tahap penyidikan. Aparat penegak hukum dalam hal ini penyidik untuk pengungkapan kasus tindak pidana yang berkaitan dengan tubuh atau jiwa manusia, dibantu oleh dokter forensik dan dalam kasus tindak pidana pembunuhan yang terjadi di wilayah hukum Polres Purworejo dapat membuat terang perkara pidana tersebut dan tujuan mencari kebenaran materiil dapat dilaksanakan dengan baik, peneliti juga mengambil kasus lain sebagai pembanding, dalam kasus ini penulis mengangkat kasus Siyono terduga teroris asal Klaten yang meninggal pada tahap penyidikan, dalam hal ini penulis mewawancarai ahli Kedokteran Forensik dr. Dirwan Suryo Sularto, Sp.F, M.Sc. selaku ahli yang dikirimkan oleh Tim kemanusian dari Komisi Perlindungan Hak Asasi Manusia, yang dimana dari hasil pemeriksaan yang dilakukan dr. Dirwan Suryo Sularto, Sp.F, M.Sc. berbanding terbalik dengan pemeriksaan yang dilakukan oleh Tim dokter forensik dari Polri, dalam hal ini menyimpulkan bahwa peran ilmu kedokteran forensik dalam membantu penyidik untuk menemukan kebenaran materiil pada perkara tindak pidana pembunuhan masih terdapat pelanggaran aturan yang terjadi, dan juga ada yang sesuai dengan aturan sehingga dapat membuat terang perkara pidana yang terjadi. Berdasarkan kenyataan dilapangan seringkali pihak kepolisian dan bantuan ilmu kedokteran forensik dalam pembuktian perkara tindak pidana pembunuhan menemui hambatan saat hendak melaksanakan pemeriksaan, diantaranya dikarenakan masayarakat kurang mengerti dan masyarakat kurang mengerti tentang tahapan pemeriksaan untuk memperoleh alat bukti. Tetapi dalam menghadapi masalah tersebut, berdasarkan KUHAP petugas harus menjelaskan dan menyadarkan pihak keluarga korban akan pentingnya pemeriksaan tersebut yang dimana akan digunakan sebagai alat pembuktian dalam usaha mencari kebenaran materiil dalam peristiwa yang menyangkut korban.

\subsection{Saran}

Berdasarkan penelitian yang telah dilakukan, penulis dapat memberikan saran Seharusnya Indonesia mempunyai lembaga independen yang mempunyai tugas dan kewenangan untuk melakukan penelitian mandiri terhadap suatu kasus tindak pidana yang sehubungan dengan tugas dokter forensik, sehingga dalam proses penegakan hukum untuk mengungkap sebuah tindak pidana tidak diketemukan lagi hasil Visum et Repertum yang keluar dari prosedur kedokteran forensik. 


\section{Daftar Pustaka}

\section{Buku}

Bambang Poernomo. (1982). Seri Hukum Acara Pidana Pandangan Terhadap Asasasas Umum Hukum Acara Pidana. Yogyakarta: Liberty.

Herkutanto. (2006). Visum et Repertum dan Pelaksanaanya. Jakarta: Ghalia.

M. Soekry Erfan Kusuma, dkk. (2012). Ilmu Kedokteran Forensik dan Medikolegal. Surabaya: Fakultas Kedokteran Universitas Airlangga.

M. Yahya Harahap. (2000). Pembahasan Permasalahan Dan Penerapan KUHAP, Pemeriksaan Sidang Pengadilan, Banding, Kasasi dan Peninjauan Kembali. Jakarta: Sinar Grafika.

Mukti Fajar. (2010). Dualisme Penelitian Hukum Normatif \& Empiris. Yogyakarta: Pustaka Pelajar.

\section{Jurnal}

Anis Nurwidayati. (2009) "Penerapan Entomologi dalam Bidang Kedokteran Forensik". Jurnal Vektor Penyakit. Vol. III, No. 2.

\section{Artikel}

ASIS, R. A. "Peranan Unit Identifikasi Dalam Proses Penyidikan Untuk Mengungkap Tindak Pidana".

\section{Wawancara}

dr. Dirwan Suryo Sularto, Sp.F., M.Sc. (2015). "Penyidikan Berbasis Ilmiah Untuk Memperoleh Alat Bukti Dalam Tindak Pidana Pembunuhan". Hasil wawancara pribadi. Fakultas Kedokteran Universitas Muhammadiyah Yogyakarta.

R. Haryo Seto. L. S.H., M. Krim. (2015). "Penyidikan Berbasis Ilmiah Untuk Memperoleh Alat Bukti Dalam Tindak Pidana Pembunuhan”. Hasil wawancara pribadi. Kantor Kepolisian Resor Purworejo. 